\title{
Environmental radioactivity of the St. Martin's island of Bangladesh
}

\author{
M.I.CHOWDHURY ${ }^{1}$, M. KAMAL ${ }^{\prime}$, M.N. ALAM ${ }^{1}$, S. AFTABUDDIN ${ }^{2}$, M. ZAFAR $^{2}$
}

(Manuscript received 20 August 2002, accepted /4 May 2003)

ABSTRACT The activity concentration of natural and anthropogenic radionuclides in soil and rock, and in benthic algae, corals and oysters across the St. Martin's island of Bangladesh were investigated together with physicochemical parameters and texture of soil with an aim of evaluating the radioecology of the island. Soil and rock samples from the twenty-two locations of the island, eleven species of benthic algae, six species of corals and two species of oysters were analyzed. The activity of ${ }^{226} \mathrm{Ra}$ in soil was found in the range of $7.22-103.8$, in benthic algae $2.5-9.7$, in coral $5.5-10$ and in oyster $4.2-11.5 \mathrm{~Bq} \mathrm{~kg}^{-1}$. The activity of ${ }^{232} \mathrm{Th}$ in soil was found in the range of 14.56-216, in benthic algae 1.3-12.6, in coral 4.4-15.6 and in oyster 3.2$8.4 \mathrm{~Bq} \mathrm{~kg} \mathrm{~kg}^{-1}$; and the activity of ${ }^{40} \mathrm{~K}$ in soil was in the range of $322-732$, in benthic algae 17.1-45.5, in coral 21-146 and in oyster $24-32 \mathrm{~Bq} \mathrm{~kg}^{-1}$. The external radiation dose rate due to activity concentration of natural radionuclides in soil was assessed. The activity of anthropogenic ${ }^{137} \mathrm{Cs}$ was found below detection limit.

RÉSUMÉ La radioactivité dans l'environnement de l'île Saint-Martin, Bangladesh.

Nous avons étudié la concentration de l'activité de radionucléides anthropogéniques dans le sol et les roches, dans les algues benthoniques, les coraux et les huîtres de l'île Saint-Martin, Bangladesh ; en même temps, nous avons considéré les paramètres physico-chimiques et la texture du sol, le but étant d'évaluer la radioécologie de l'île. Nous avons analysé des échantillons du sol et de roches venant de 22 endroits de l'île, onze espèces d'algues benthoniques, six espèces de coraux et deux espèces d'huîtres. Nous avons trouvé que l'activité de ${ }^{226}$ Ra dans le sol était dans la fourchette de $7,22-103,8 \mathrm{~Bq} \mathrm{~kg}^{-1}$, dans les algues benthoniques de 2,5-9,7, dans le corail de 5,5-10, et dans les huîtres de 4,2-11,5. En ce qui concerne ${ }^{232} \mathrm{Th}$, nous avons obtenu dans le sol la fourchette de 14,56-216, dans les algues benthoniques $1,3-12,6$, dans le corail 4,4-15,6, dans les huîtres 3,2-8,4, toujours en $\mathrm{Bq}^{-1} \mathrm{~g}^{-1}$; l'activité de ${ }^{40} \mathrm{~K}$ se situait dans le sol entre 322 et $732 \mathrm{~Bq} \mathrm{~kg}^{-1}$, dans les algues benthoniques entre 17,1 et 45,5 , dans le corail entre 21 et 146, dans les huîtres entre 24 et 32 . Nous avons mesuré le débit de dose, pour le rayonmement externe dû à la concentration de l'activité des radionucléides naturels dans le sol. Nous avons constaté que l'activité du ${ }^{137} \mathrm{Cs}$ anthropogénique est au-dessous de la limite de détection.

\section{Introduction}

St. Martin's Island is a coral rich island of Bangladesh, lies about $12 \mathrm{~km}$ off from the main land of Bangladesh towards south, situated between $92^{\circ} 18^{\prime} \mathrm{E}-92^{\circ} 2 \mathrm{I}^{\prime} \mathrm{E}$

\footnotetext{
1 Radioncrivity Testing and Monitoring Laboratory, Bangladesh Atomic Energy Commission, P.O. Box 1352, Chittagong. Banglade sh.

Institule of Marine Sciences, L'niversity of Chittagong, Chittagong. Bangladesh.
} 


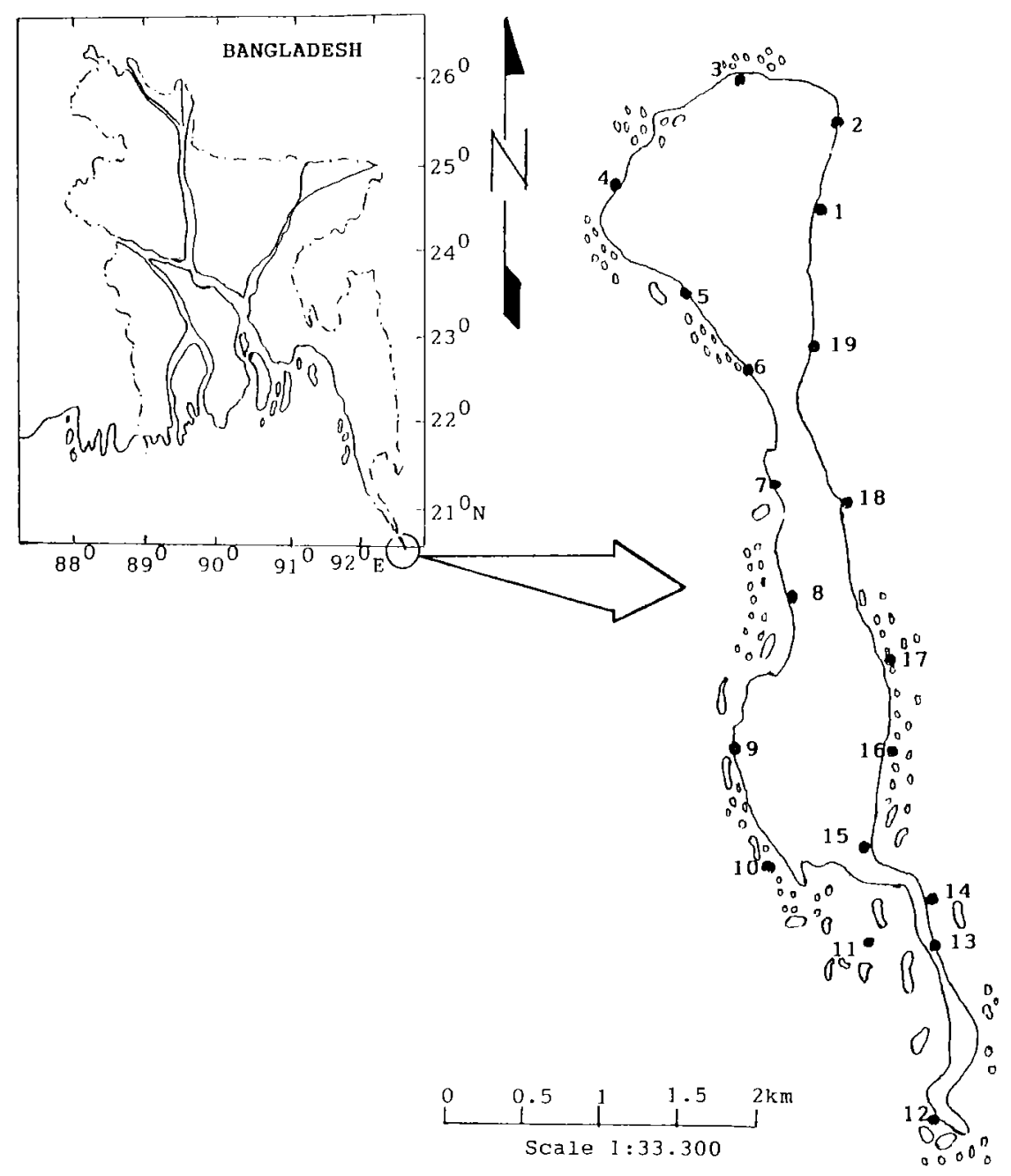

Figure 1 - Study area and sampling locations of St. Martin's island of the bay of Bengal, Bangladesh.

Région étudiée et emplacements des échantillons de l'île Saint-Martin, baie du Bengale, Bangladesh.

longitude and $20^{\circ} 34^{\prime} \mathrm{N}-20^{\circ} 38^{\prime} \mathrm{N}$ latitude in the north-eastern part of the Bay of Bengal (Fig. 1). The island presents a variety of physiographic features-rocky platform, sandy beach, sand dunes, a lagoon, marshes, a tumble, crenulated shoreline and coral clusters. The rocks are made of argillaceous limestone, 
calcareous sand stones, fossiliferous conglomerates and coralline limestone and are lie in the form of a thin sheet and also in the shape of big rough boulders (Chowdhury et al., 1992). The island exposes a sequence of marine sedimentary rock ranging in age from the late Miocene to recent. The fossiliferous marine horizon, the southern part formation presumably of late Miocene age, is the most important and is overlain by coquina bed of Pleistocene age, and alluvium and beach sands of Holocene age. Fishing in the reef areas is one of the main economic activities. People of the island use the fossil coral as buoy and building material thus destroying the fossil coral, on the other hand living corals are extracted for being sold as show pieces. Local people are exploiting large quantity of coral every year for commercial purposes. Reef is under threat of destruction as a result of human activities like agricultural practices, destructive fishing methods, tourist activities and extraction of rocks etc. It is evident that bivalve mollusks have been the most commonly used bioindicators to date, because bivalves confirm well to the basic prerequisites of an indicator species, are often consumed as seafood, and are ubiquitous in most coastal marine ecosystems. Mussels, oysters and clams are the species most frequently chosen, and their use has lead to "Mussel Watch" type pollution monitoring programs throughout the world. Macro (Benthic) algae, which enter the human diet, consist of Rhodophyceae (red), Chlorophyceae (green) and Phaephyceae (brown) species, red and green algae are directly consumed in many countries, but brown algae are largely taken for conversion into alginates. There are exceptions, some Phaephyceae are consumed in China, Japan and other far-eastern countries, but probably not in large quantities.

The present work initiate a environmental radioactivity assessment program for St. Martin's island of the bay of Bengal, with the aim of establishing a baseline map of radioactivity background levels in the island environment. The activity of radionuclides in soil and rock, algae, coral and oyster collected from the island were studied in respect of physico-chemical parameters of the area.

\section{Materials and methods}

\subsection{Collection and preparation of sample}

Soil and rock samples were collected from the 22 stations of the island at a depth of $15 \mathrm{~cm}$ from the surface using a soil corer. The samples were weighed and transported to the laboratory in sealed plastic sample bags. They were air-dried, ground and again dried in an oven at $105^{\circ} \mathrm{C}$ for 24 hours and passed through a $2 \mathrm{~mm}$ mesh sieve to collect the finely powdered sample. The known amount of samples were then packed in plastic containers, sealed and kept stand for 4 weeks to reach secular equilibrium between the ${ }^{226} \mathrm{Ra}$ and ${ }^{232} \mathrm{Th}$ series and most of their 
respective progeny. A portion of the soil samples were used for the measurement of physico-chemical parameters. Eleven species of seaweed (algae) samples were collected from the exposed rock surfaces of the island during the lowest low tide. They were washed with clean seawater and kept in plastic bags. The algae later rinsed in de-ionized double distilled water to remove much of the adventitious salts, dried in oven at $80^{\circ} \mathrm{C}$ for 24 hours. The dried product was broken by hand into small pieces, ground to a fine powder in a porcelain cup, weighed and packed in the plastic containers. During the lowest low tide six species of coral and two species of oyster were collected from the intertidal zone at a depth of about 1 meter with the aid of hammer and chisel. The samples were washed with clean seawater, sun-dried and taken to the laboratory for identification, preparation and measurement.

\subsection{Measurement}

The detection and measurement of the radionuclides in soil, algae, coral and oyster samples were carried out by $\gamma$-ray spectrometry using $111 \mathrm{~cm}^{3}$ intrinsic p-type coaxial HPGe detector with a relative efficiency of $23 \%$ and a resolution of $1.77 \mathrm{keV}$ (FWHM) for the peak of $1332 \mathrm{keV}$ of ${ }^{60} \mathrm{Co}$. The full-energy-peak efficiency of the detector was measured using the IAEA reference samples IAEA/FISH FLESH MA-B-3/RN, IAEA-312 soil sample and IAEA/RG samples of uranium, thorium and potassium radionuclides (AQCS, 1995). The $\gamma$-ray energies of ${ }^{212} \mathrm{~Pb}(238.63 \mathrm{keV}),{ }^{212} \mathrm{Bi}(727.17 \mathrm{keV}),{ }^{208} \mathrm{Tl}(583.2 \mathrm{keV})$ and ${ }^{228} \mathrm{Ac}$ $(338.4,911$ and $969 \mathrm{keV})$ were used to determine the activity of ${ }^{232} \mathrm{Th}$. The $\gamma$-ray transitions of ${ }^{214} \mathrm{Bi}(609.3,1120.3$ and $1764.5 \mathrm{keV})$ and ${ }^{214} \mathrm{~Pb}(295.2$ and $351.9 \mathrm{keV}$ ) were used to determine the activity of ${ }^{226} \mathrm{Ra}$. The ${ }^{40} \mathrm{~K}$ and ${ }^{137} \mathrm{Cs}$ radionuclides were measured from their respective $\gamma$-ray energies 1460 and $661.66 \mathrm{keV}$, respectively (IAEA, 1989; ICRP, 1983; Ibrahiem et al., 1995). The geometry of the counting samples was the same as that of the standard samples and the counting time for all the samples were $50000 \mathrm{~s}$. The absorbed gamma dose rate in outdoor air due to natural radionuclides from the soil at one meter above the surface was estimated using the conversion factor given in UNSCEAR (1988).

\section{Results and discussion}

The physico-chemical parameters viz. $\mathrm{pH}$, salinity, temperature, electric conductivity and organic matter in the soil and rock samples are shown in Table I. The activity concentration of ${ }^{226} \mathrm{Ra},{ }^{232} \mathrm{Th}$ and ${ }^{40} \mathrm{~K}$ in dry weight of soil and rock and the outdoor absorbed dose rate at one meter above the ground surface was calculated from the activity concentrations of natural radionuclides are shown in Table II. The dose rate due to natural radionuclides in soil and rock at one meter 
TABLE I

Physico-chemical parameters and texture of soil of the St. Martin's island. Paramètres physico-chimiques et texture du sol de l'île Saint-Martin.

\begin{tabular}{lccc}
\hline Parmoters & Range & Parameters & Pange \\
\hline No. of sampling locations & 22 & Organic carbon, \% & $0.09-0.30$ \\
No. of samples & 66 & Organic matter, $\%$ & $0.15-0.51$ \\
pH of the soil & $7.81-8.78$ & Sand. \% & $90.2-99.32$ \\
Salinity $(\%)$ & $19.48-47.74$ & Silt, $\%$ & $0.28-3.64$ \\
Electric conductivity, $\mathrm{SS} \mathrm{cm}^{-1}$ & $2.6-6.6$ & Clay, $\%$ & $0.12-6.45$ \\
\hline
\end{tabular}

above the ground surface is in the range $0.31 \mathrm{mSv}^{-1}$ to $1.84 \mathrm{mSv}^{-1}$ with an average value of $0.53 \mathrm{mSv} \mathrm{a}^{-1}$.

In soil and rock, the activity concentration of ${ }^{40} \mathrm{~K}$ is ranged from $322 \pm 25$ to $732 \pm 20 \mathrm{~Bq} \mathrm{~kg}^{-1}$ with an average of $480 \pm 88 \mathrm{~Bq} \mathrm{~kg}^{-1}$. The lowest value was found in the sandy soil of the western coast while the highest value was observed in the middle of the island. In our previous works on Cox's Bazar area beach $\left(21^{\circ} 25^{\prime} \mathrm{N}\right.$, $92^{\circ} 10^{\prime} \mathrm{E}$ ), the average activity of ${ }^{40} \mathrm{~K}$ in soil was observed $458.23 \pm 30.22 \mathrm{~Bq} \mathrm{~kg}^{-1}$ (Alam et al., 1999), in the salt pans soil of Cox's Bazar $\left(21^{\circ} 30^{\prime} \mathrm{N}, 92^{\circ} 0^{\prime} \mathrm{E}\right)$, Moheshkhali $\left(21^{\circ} 30^{\prime} \mathrm{N}, 92^{\circ} 55^{\prime} \mathrm{E}\right)$ and Chakaria $\left(21^{\circ} 45^{\prime} \mathrm{N}, 92^{\circ} 0^{\prime} \mathrm{E}\right)$ was in the range of $383 \pm 35$ to $652 \pm 66 \mathrm{~Bq} \mathrm{~kg}^{-1}$ (Alam et al., 1997a), and in sediments of the Karnaphuli estuary $\left(22^{\circ} 20^{\prime} \mathrm{N}, 91^{\circ} 5 \mathrm{l}^{\prime} \mathrm{E}\right)$ of the bay of Bengal in the range of $118 \pm 20$ to $608 \pm 76 \mathrm{~Bq} \mathrm{~kg}^{-1}$ (Alam et al., 1997b).

The activity of ${ }^{226} \mathrm{Ra}$ in soil and rock of the island is ranged from $7.22 \pm 0.86$ to $103.75 \pm 6.33 \mathrm{~Bq} \mathrm{~kg}^{-1}$ with an average of $23.15 \pm 17.8 \mathrm{~Bq} \mathrm{~kg}^{-1}$, lowest value was observed in the eastern coast, while the highest value was in the western coast. The observed value of ${ }^{226} \mathrm{Ra}$ is higher than that of sediments of Cox's Bazar beach soil which is ranged from $10.85 \pm 1.64-27.33 \pm 2.61 \mathrm{~Bq} \mathrm{~kg}^{-1}$ with an average of $18.89 \pm 2.16 \mathrm{~Bq} \mathrm{~kg}^{-1}$ (Alam et al., 1999), and from the Karnaphuli river estuary which is ranged from $5.87 \pm 1,21-27.85 \pm 1.71 \mathrm{~Bq} \mathrm{~kg}^{-1}$ (Alam et al., 1997b).

The activity of ${ }^{232}$ Th observed in soil and rock of the island is ranged from $14.56 \pm 1.58$ in Dakhinpara for sandy soil to $216 \pm 9.75 \mathrm{~Bq} \mathrm{~kg}^{-1}$ at western coast of Siradia area for coastal sand with an average of $45.12 \pm 38.82 \mathrm{~Bq} \mathrm{~kg}^{-1}$ which is higher than that of the activity of ${ }^{232}$ Th in the Cox's Bazar beach soil $(36.67 \pm$ $4.26 \mathrm{~Bq} \mathrm{~kg}{ }^{-1}$; Alam et al., 1999) and in sediment of the Karnaphuli estuary $\left(10.44 \pm 2.31\right.$ to $64.02 \pm 8.13 \mathrm{~Bq} \mathrm{~kg}^{-1}$; Alam et al., 1997b). In soil and rock, the activity of ${ }^{137} \mathrm{Cs}$ was below detection limit of $40 \mathrm{mBq} \mathrm{kg}{ }^{-1}$. 


\section{TABLE II}

Activity of radionuclides $\left(\mathrm{Bq} \mathrm{kg} \mathrm{g}^{-1} \mathrm{dry} \mathrm{wt}\right)$ in soil and rock of St. Martin's island. Activité de radionucléides ( $\left.\mathrm{Bq} \mathrm{kg}^{-1} \mathrm{sec}\right)$ dans le sol et les roches de l'île Saint-Martin.

\begin{tabular}{|c|c|c|c|c|}
\hline SI. & ${ }^{226} \mathrm{Na}_{\mathrm{q}}$ & $(232 \mathrm{~T}$ & ${ }^{40} \mathrm{~K}$ & Bose nth, msy a \\
\hline 1 & $14.91 \pm 3.34$ & $41.28 \pm 5.08$ & $417 \pm 27$ & 0.45 \\
\hline 2 & $20.54 \pm 3.77$ & $35.85 \pm 5.39$ & $484 \pm 28$ & 0.47 \\
\hline 3 & $19.95 \pm 3.96$ & $29.21 \pm 4.56$ & $425 \pm 27$ & 0.40 \\
\hline 4 & $26.90 \pm 3.49$ & $44.50+5.21$ & $409 \pm 28$ & 0.51 \\
\hline 5 & $34.06 \pm 2.73$ & $67.35 \pm 3.86$ & $322 \pm 25$ & 0.64 \\
\hline 6 & $15.81 \pm 1.90$ & $15.37 \pm 2,46$ & $495 \pm 27$ & 0.33 \\
\hline 7 & $10.84 \pm 1.81$ & $17.92 \pm 2.48$ & $460 \pm 25$ & 0.32 \\
\hline 8 & $19.53 \pm 1.61$ & $26.10 \pm 2.80$ & $434 \pm 27$ & 0.39 \\
\hline $9^{\mathrm{a}}$ & $28.37 \pm 1.81$ & $43.54 \pm 3.52$ & $557 \pm 30$ & 0.57 \\
\hline $9^{b}$ & $19.72 \pm 1.69$ & $57.54 \pm 3.02$ & $430 \pm 24$ & 0.57 \\
\hline $10^{3}$ & $21.37 \pm 2.40$ & $49.26 \pm 3.35$ & $457 \pm 28$ & 0.54 \\
\hline $10^{b}$ & $22.05 \pm 3.71$ & $24.61 \pm 6.19$ & $421 \pm 25$ & 0.38 \\
\hline 11 & $13.37 \pm 3.35$ & $30.68 \pm 5.65$ & $497 \pm 29$ & 0.41 \\
\hline 12 & $103.8 \pm 6.33$ & $216.0 \pm 9.75$ & $541 \pm 28$ & 1.84 \\
\hline 13 & $23.71 \pm 3.72$ & $71.82 \pm 5.60$ & $492 \pm 28$ & 0.69 \\
\hline $14^{\sharp}:$ & $21.57 \pm 4.0$ & $26.97 \pm 5.43$ & $599+29$ & 0.46 \\
\hline $14^{b}$ & $14.92 \pm 29.7$ & $20.44 \pm 4.48$ & $372=24$ & 0.31 \\
\hline 15 & $7.22 \pm 0.86$ & $14.56 \pm 1.58$ & $565 \pm 14$ & 0.32 \\
\hline 16 & $13.52 \pm 1.82$ & $23.70 \pm 2.54$ & $472 \pm 16$ & 0.37 \\
\hline 17 & $22.29 \pm 1.90$ & $46.98 \pm 3.92$ & $497 \pm 14$ & 0.54 \\
\hline 18 & $22.45 \pm 3.19$ & $49,43=6,02$ & $421 \pm 18$ & 0.53 \\
\hline 19 & $21.42 \pm 3.26$ & $39.38 \pm 4.78$ & $546 \pm 19$ & 0.51 \\
\hline 20 & $20.83 \pm 2.68$ & $45.41 \pm 5.21$ & $732 \pm 20$ & 0.62 \\
\hline 21 & $26.09 \pm 1.91$ & $55.73 \pm 2.06$ & $358 \pm 6.4$ & 0.55 \\
\hline 22 & $13.46 \pm 1.13$ & $34.55 \pm 2.28$ & $587+9.4$ & 0.48 \\
\hline
\end{tabular}

${ }^{a}$ Soil sample, ${ }^{b}$ rock sample.

\subsection{Concentration of radionuclides in benthic algae}

For many reasons marine macro algae are excellent organisms for use in monitoring programs. Algae are key links in benthic food webs and are of direct economic importance to man as well their size and sedentary nature facilitates rapid collection of large amounts of material. The activity of ${ }^{40} \mathrm{~K}$ in the seaweed was observed in the range of $17.1 \pm 1.0-45.5 \pm 4.2 \mathrm{~Bq} \mathrm{~kg}^{-1}$ with an average of $26.65 \pm 9.32 \mathrm{~Bq} \mathrm{~kg}^{-1}$ of wet weight. Higher concentration of ${ }^{40} \mathrm{~K}$ was found 
TABLE III

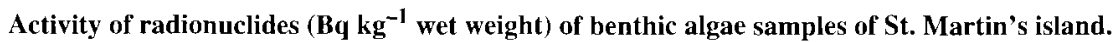
Activité de radionucléides ( $\mathrm{Bq} \mathrm{kg}^{-1}$ humide) dans des algues benthoniques de l'île Saint-Martin.

\begin{tabular}{|c|c|c|c|c|}
\hline \multirow{2}{*}{ SI: } & \multirow[t]{2}{*}{ Benthic algae } & ${ }^{22 \sigma_{\mathbf{R a}}}$ & \multirow{2}{*}{$\begin{array}{c}{ }^{2 z_{\mathrm{Th}}} \\
\mathrm{Bq} \mathrm{kg}^{-1} \text { frow whit }\end{array}$} & \multirow{2}{*}{$\begin{array}{c}40 \mathrm{X} \\
\end{array}$} \\
\hline & & (3) & & \\
\hline 1 & Gracilariasp. & $3.4 \pm 1.6$ & $2.3 \pm 0.9$ & $17.3 \pm 1.2$ \\
\hline 2 & Dictyota cillolata & $4.0 \pm 1.8$ & $1.3 \pm 0.6$ & $17.1 \pm 1.0$ \\
\hline 3 & Dictrota dichotoma & $9.0 \pm 2.2$ & $9.4 \pm 2.3$ & $41.7 \pm 3.4$ \\
\hline 4 & Dictyopteris austrailis & $6.0 \pm 2.3$ & $12.6 \pm 5.1$ & $45.5 \pm 4.2$ \\
\hline 5 & Sargussum ilicofilium & $4.8 \pm 1.4$ & $6.2 \pm 2.4$ & $25.2 \pm 3.0$ \\
\hline 6 & Sargussam filipendula & $9.7 \pm 2.3$ & $3.9 \pm 3.1$ & $20.0 \pm 1.2$ \\
\hline 7 & Padinasp. & $7.3 \pm 2.2$ & $7.5 \pm 4.3$ & $28.0 \pm 3.7$ \\
\hline 8 & Sargussum tenerimum. & $5.8 \pm 2.0$ & $3.0 \pm 5.2$ & $21.2 \pm 2.2$ \\
\hline 9 & Hydroclathras clathras. & $8.2 \pm 2.4$ & $4.4 \pm 3.7$ & $24.2 \pm 2.6$ \\
\hline 10 & Crysymenia sp: & $2.5 \pm 0.5$ & $5.0 \pm 2.3$ & $30 \pm 3.4$ \\
\hline 11 & Hypneasp. & $3.6 \pm 1.2$ & $5.7 \pm 0.6$ & $23 \pm 2.2$ \\
\hline
\end{tabular}

in Dictyopteris austrailis. The activity of ${ }^{226} \mathrm{Ra}$ is ranged from $2.5 \pm 0.5-9.7 \pm$ $2.3 \mathrm{~Bq} \mathrm{~kg}^{-1}$ of wet weight. The lowest activity was found in Crysymenia sp. and the highest activity was found in Sargussam filipendula. These species were mostly found growing on the boulders and rocks of back rock pools and sheltered calm rock pools of the intertidal and sub littoral zone. The activity of ${ }^{232} \mathrm{Th}$ in these seaweed's is ranged from $1.3 \pm 0.6-12.6 \pm 5.1 \mathrm{~Bq} \mathrm{~kg}^{-1}$ of wet weight. Higher concentration was observed in Dictyopteris austrailis. Table III shows the activity concentration of radionuclides present in various species of benthic algae. In algae, the activity of ${ }^{137} \mathrm{Cs}$ was below detection limit.

\subsection{Concentration of radionuclides in corals and oysters}

The activity of radionuclides in corals is shown in Table IV. The activity of ${ }^{226} \mathrm{Ra}$ found in coral samples is in the range of $5.5 \pm 1.4-10 \pm 1.8 \mathrm{~Bq} \mathrm{~kg}^{-1}$ with an average of $8.63 \pm 1.64 \mathrm{~Bq} \mathrm{~kg}^{-1}$, the highest activity of ${ }^{226} \mathrm{Ra}$ was observed in $P$. daedala. The activity of ${ }^{232} \mathrm{Th}$ in coral is ranged from $4.4 \pm 1.2-15.6 \pm$ $2.5 \mathrm{~Bq} \mathrm{~kg}^{-1}$ with an average of $10 \pm 3.8 \mathrm{~Bq} \mathrm{~kg}^{-1}$ and the activity of ${ }^{40} \mathrm{~K}$ is ranged from $21 \pm 5-146 \pm 11 \mathrm{~Bq} \mathrm{~kg}^{-1}$ with an average of $77.5 \pm 42 \mathrm{~Bq} \mathrm{~kg}^{-1}$. The highest activity of ${ }^{232} \mathrm{Th}$ and ${ }^{40} \mathrm{~K}$ was observed in Cyphastrea serailia.

The radioactivity of oysters is shown in Table $\mathrm{V}$. The activity of ${ }^{226} \mathrm{Ra}$ in the oyster shell is ranged from $6.2 \pm 1.5-11.5 \pm 2.0 \mathrm{~Bq} \mathrm{~kg}^{-1}$ with an average of $8.85 \pm 3.75 \mathrm{~Bq} \mathrm{~kg}^{-1}$. The activity of ${ }^{232} \mathrm{Th}$ in the oyster shell is ranged from 
TABLE IV

Activity of radionuclides (Bq $\mathrm{kg}^{-1} \mathrm{dry} \mathrm{wt}$ ) in coral samples of the St. Martin's island. Activité de radionucléides $\left(\mathrm{Bq} \mathrm{kg}^{-1} \mathrm{sec}\right)$ dans des échantillons du corail de l'île Saint-Martin.

\begin{tabular}{|c|c|c|c|c|c|}
\hline S1. & Name of corals & 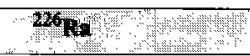 & 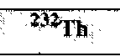 & , 10 & \\
\hline 1 & Lepastrea transversa & $5.5 \pm 1.4$ & $4.4 \pm 1.2$ & $68 \pm 6$ & \\
\hline 2 & Fovites haticera & $9.9 \pm 1.7$ & $9.5 \pm 1.5$ & $74 \pm 8$ & \\
\hline 3 & Platygyra sinensis & $8.8 \pm 1.8$ & $11.6 \pm 2.0$ & $96 \pm 8$ & \\
\hline 4 & Goniastrea spp. & $8.9 \pm 1.2$ & $7.9 \pm 1.8$ & $21 \pm 5$ & \\
\hline 5 & P daedala & $10 \pm 1.8$ & $11.0 \pm 2.1$ & $60 \pm 7$ & \\
\hline 6 & Cyphtastrea serailia & $8.6 \pm 1.7$ & $15,6 \pm 2.5$ & $146 \pm 11$ & \\
\hline
\end{tabular}

TABLE V

Activity ( $\mathrm{Bq} \mathrm{kg} \mathrm{dry}^{-1}$ weight) of oyster samples of the St. Martin island. Activité ( $\left.\mathrm{Bq} \mathrm{kg}^{-1} \mathrm{sec}\right)$ d'échantillons d'huîtres de l'île Saint-Martin.

\begin{tabular}{|c|c|c|c|c|}
\hline S1. & Name of sannoles & $220 \mathrm{Rs}$ & Wry & 40 \\
\hline \multicolumn{5}{|c|}{ Crassostreasp. } \\
\hline 1 & shell & $11.5 \pm 2.0$ & $7.7 \pm 1.5$ & $24 \pm 3.4$ \\
\hline 2 & soft tissue & $4.2 \pm 1.0$ & $3.2 \pm 0.7$ & $30 \pm 3.7$ \\
\hline \multicolumn{5}{|c|}{ Saccostreasp. } \\
\hline 1 & shell & $6.2 \pm 1.5$ & $5.4 \pm 1.2$ & $28 \pm 3.5$ \\
\hline 2 & seft tissue & $4.6 \pm 1.2$ & $8.4 \pm 1.8$ & $32 \pm 4,0$ \\
\hline
\end{tabular}

$5.4 \pm 1.2-7.7 \pm 1.5 \mathrm{~Bq} \mathrm{~kg}^{-1}$ with an average of $6.55 \pm 1.63 \mathrm{~Bq} \mathrm{~kg}^{-1}$ and the activity of ${ }^{40} \mathrm{~K}$ is ranged from $24 \pm 8.6-28 \pm 9.5 \mathrm{~Bq} \mathrm{~kg}^{-1}$ with an average of $26 \pm$ $2.83 \mathrm{~Bq} \mathrm{~kg}{ }^{-1}$. The activity of ${ }^{226} \mathrm{Ra}$ in the soft tissues is in the range of $4.2 \pm$ $1.0-4.6 \pm 1.2$ with an average of $4.4 \pm 0.28 \mathrm{~Bq} \mathrm{~kg}^{-1},{ }^{232} \mathrm{Th}$ in the soft tissues is ranged from $3.2 \pm 0.7-8.4 \pm 1.8 \mathrm{~Bq} \mathrm{~kg}^{-1}$ with an average of $5.8 \pm 3.68 \mathrm{~Bq} \mathrm{~kg}^{-1}$ and the activity of ${ }^{40} \mathrm{~K}$ is ranged from $30 \pm 3.7-32 \pm 4.0 \mathrm{~Bq} \mathrm{~kg}^{-1}$ with an average of $31 \pm 1.41 \mathrm{~Bq} \mathrm{~kg}^{-1}$.

\section{Conclusion}

The activity concentration of naturally occurring radionuclides observed in the soil and rock of the St. Martin's island was within the range of world value published in the UNSCEAR (1988). Low level of activity concentration of naturally occurring radionuclides was observed in the samples of algae, corals and shell and soft tissues of oyster of the island. The activity of anthropogenic ${ }^{137} \mathrm{Cs}$ was not observed in any of the samples of soil, rock, algae, corals or oyster of the island. 


\section{REFERENCES}

Alam M.N., Chowdhury M.I., Kamal M., Ghose S., Zafar M., Kamal A.H.M. (1997a) Radionuclide concentrations in salt pans ecology in the coastal area of Cox"s Bazar, Bangladesh, J. Environm. Rad. 41(3), 257-267.

Alam M.N., Chowdhury M.I., Kamal M., Ghose S., Mahmood N., Matin A.K.M.A., Saikat S.Q. (1997b) Radioactivity in sediments of the Bay of Bengal, Health Phys. 73(2), 385-387.

Alam M.N., Chowdhury M.I., Kamal M., Ghose S., Islam M.N., Mostafa M.N., Miah M.M.H., Ansary M. (1999) The ${ }^{226} \mathrm{Ra},{ }^{232} \mathrm{Th}$ and ${ }^{40} \mathrm{~K}$ activities in Beach Sand Minerals and Beach Soils of Cox's Bazar, J. Environm. Rad. 46(3), 243-250.

AQCS (1995) Intercomparison Runs Reference Materials. Analytical Quality Control Services. IAEA, Vienna, Austria.

Chowdhury S.Q., Hoque A.T.M., Hassan M.K. (1992) Coastal Geomorphology of St. Martin's Islan, Orient. Geograph. 36(2), 30-43.

IAEA (1989) Measurement of Radionuclides in food and the Environment. Technical Report series No. 295, International Atomic Energy Agency, Vienna, Austria.

Ibrahiem N.M., Shawky S.M., Amer H.A. (1995) Radioactivity levels in Lake Nasser sediments, Appl. Rad. Isotop. 46, 620-627.

ICRP Publication 38 (1983) Radionuclide Transformations: Energy and Intensity of Emissions, Ann. ICRP 11-13.

UNSCEAR (1988) United Nations Scientific Committee on the effects of Atomic Radiation. Exposures from natural Source of radiation. Report to the General Assembly, UN, NY, USA. 